\title{
Isabel Restrepo Jaramillo. Narrativas de la historia en \\ el audiovisual colombiano. Controversias sobre el pasado en cuatro estudios de caso comparados. Medellín:
}

Universidad de Antioquia, Facultad de Ciencias Sociales y Humanas, Fondo Editorial FCSH, 2019, 144 pp.

Yubely Vahos Hernández*

$\mathrm{E}^{1}$ libro Narrativas de la historia en el audiovisual colombiano parte de la idea de que ha existido una conexión entre la historia en cuanto disciplina y las representaciones del pasado que han sido vertidas en el audiovisual colombiano con enfoque retrospectivo. Con la intención de comprender la filigrana de lo anterior, la historiadora Isabel Restrepo Jaramillo ha optado por la comparación de cuatro casos: Garras de oro, los documentales de Marta Rodríguez y Jorge Silva; El profesor Super O histórico y los documentales que integran la Caja Viajera del Grupo de Memoria Histórica (GMH). La investigación adelantada por la autora le permite sostener que los audiovisuales con intencionalidad retrospectiva dialogan con argumentos desarrollados por la historiografia y los actualizan de acuerdo con las coyunturas del entorno de producción de las obras, al tiempo que transmiten una comprensión de la historia ligada tanto a corrientes historiográficas como a proyectos políticos o reivindicaciones sociales. En consecuencia, los productos audiovisuales emplean el pasado para hablar del tiempo en que vieron la luz.

El mayor aporte del libro reside en que la autora no cuestiona la correspondencia entre la representación en las pantallas y el conocimiento histórico surgido en las universidades sobre lo que probablemente sucedió. En lugar de ello, hace hincapié en el hecho que los realizadores normalmente no acceden a los datos del pasado que se conservan en los archivos, sino a las interpretaciones esgrimidas por los historiadores y resalta que es con ellas que los creadores debaten o se alinean. De esta manera, para comprender la forma en que ha sido representado el pasado en películas, series y documentales indaga sobre cómo los creadores interactuaron con la historia escrita y las narrativas que estaban siendo producidas por los historiadores sobre el proceso escenificado en las pantallas en el lapso en que fue realizado.

* Estudiante de la maestría en Comunicaciones de la Universidad de Antioquia. Miembro del Grupo de Investigación en Historia Social (GIHS) de la Universidad de Antioquia. 
Pero el argumento de la autora va más allá: desde su perspectiva, los creadores de discursos audiovisuales urden representaciones del pasado que ayudan a perpetuar visiones de cierto sector social avaladas por la historia escrita, reabren el debate sobre interpretaciones que la historiografia ha legitimado o subvierten el pasado tal como ha sido narrado, al tiempo que invitan a los historiadores a reflexionar sobre el particular. Para Restrepo Jaramillo, la escritura y las imágenes en movimiento (acompañadas de sonido o silentes) son dos formas legítimas de hacer historia que se observan, se actualizan al descubrirse en la otra y se llaman a debate, con el agregado de que la mayor difusión del audiovisual convoca a la historiografia a dar cuenta de sus ideas más allá del entorno académico.

Restrepo Jaramillo presta particular atención a los usos de las imágenes, las formas que adopta el discurso en cada producción y la organización narrativa en los casos elegidos para relacionar los modos de representación con las apuestas sociales de los directores. Por ejemplo, para la autora la manera en que son presentadas ciertas imágenes da cuenta de la continuidad o ruptura entre pasado y presente que percibe el realizador, así como de su interés por denunciar la canonización de versiones del pasado consignadas en la historia escrita. Ella postula, de la mano de pensadores de la comunicación, una "servidumbre del producto audiovisual respecto al momento de su realización” (p. 14). Esto implica comprender toda apuesta estética como una elección orientada a enlazar las ideas de la historia presentadas en la obra con símbolos cuyo sentido era conocido en el tiempo de su exhibición; al asumir que la unión de ambos aspectos se tornaba en el vehículo que instalaba el sentido de la representación en el espectador.

A lo largo del libro no se deja de lado la relación entre el presente de cada producción estudiada y las narrativas históricas escenificadas en el producto mismo. Ello obedece a que, para Restrepo Jaramillo, las relaciones que el audiovisual establece con la historia escrita, así como la escenificación de la postura que sus creadores eligen defender, tienen la función de posicionar sus versiones del pasado y, con ellas, a la historiografía con que dialogan en las disputas por la memoria. Con el fin de dar cuenta de este procedimiento, la autora se centra en cuatro escenarios de controversia: la enseñanza de la historia, la memoria del conflicto, las luchas sociales de los indígenas y el sentido de nación frente a un gobierno extranjero, al analizar dos producciones estatales y dos divergentes.

A las estatales las une la pretensión de objetividad de los investigadores y las entidades que las produjeron, además de su pertenencia a dos proyectos más amplios: la reivindicación de la memoria de las víctimas del conflicto colombiano y la conmemoración de los doscientos años de la independencia del país. No obstante, la autora lee en los capítulos de El profesor Super O histórico que se emplean recursos narrativos y visuales innovadores para reproducir la misma historia centralista, blanca y criolla, construida a la manera tradicional que representan los manuales de historia escolar desde el siglo XX. En el caso de los documentales del GMH, la autora interpreta que, a diferencia de los informes publicados por esta entidad, se instaura una memoria oficial que omite tanto los procesos conflictivos del pasado 
como las implicaciones políticas de su apuesta selectiva de memoria y que se centra en el acto mismo de recordar en el presente.

Si estos productos consagran una historia que se pretende definitiva, a los audiovisuales divergentes los une el propósito de combatir algunos de los presupuestos que han defendido las instituciones estatales. Los documentales de Rodríguez y Silva se oponen a la historiografia de la Academia Colombiana de Historia y rescatan la historia de las luchas de grupos sociales excluidos de la escritura del pasado y del ejercicio de sus derechos con el propósito de potenciar sus búsquedas de cambio. Garras de oro opone, al pacto de olvido que Colombia había suscrito frente a la pérdida de Panamá, la idea de que el pasado es un escenario de disputas que representa bajo la forma de un juicio simbólico con fuentes históricas, además de asumir una postura nacionalista al condenar al gobierno estadounidense.

La diversidad de temporalidades de producción y de preguntas realizadas a las obras audiovisuales se ve reflejada en la variedad de referentes empleados en el libro. Sin embargo, dos grupos de autores acompañan a la investigadora en el tejido de sus argumentos: teóricos sobre las representaciones en la historia como Peter Burke o Frank Ankersmit, y sobre la memoria, entre los que se destaca la presencia de Elizabeth Gelin. Con estos insumos que orientan su lectura de las fuentes historiográficas y audiovisuales, la autora desarrolla con suficiencia el planteamiento correspondiente a la representación de los discursos de la historia.

Ahora bien, en el libro se descuida la parte del problema que atañe a los historiadores. Si las narrativas de la historia son referidas e interpeladas en el audiovisual retrospectivo, como demuestra la autora, ¿qué lugar ocupan los historiadores? Restrepo Jaramillo establece relaciones entre la historiografia y el producto audiovisual, muestra las nociones de la historia de los creadores, pero no da cuenta de si existieron relaciones entre historiadores y realizadores que ayudaran a darle sentido al contenido audiovisual, o si los investigadores han respondido a las representaciones de su saber en otros formatos.

En suma, hacen falta algunas puntadas en torno a la otra parte del diálogo, que amplíen la comprensión de los asuntos tratados en el libro. Esta retroalimentación resulta aun más deseable y factible en el capítulo relativo a los documentales de Marta Rodríguez y Jorge Silva, ya que en las décadas de los setenta y ochenta los representantes de la nueva historia convergieron con intelectuales de diverso pelambre en la lucha por comprender la complejidad de la sociedad nacional. Si bien el diálogo se estableció en doble vía, en el libro solo percibimos la parte correspondiente a los realizadores.

El valor historiográfico de la obra reside en que se une al llamado de otros investigadores que claman por ampliar la definición de los productos que merecen ser asumidos como fuentes para la comprensión del pasado y por reconocer que no existe un monopolio de enunciación materializado en los centros académicos de investigación histórica. El texto de Restrepo Jaramillo aporta a este movimiento al cuestionar la noción que las versiones del pasado que presentan las piezas audiovisuales poseen menos poder explicativo que los libros, artículos y 
ponencias surgidos de la mano de los historiadores. Al plantear que las representaciones escenificadas en los audiovisuales retrospectivos despliegan, al igual que la historiografia, apuestas sociales y de memoria sustentadas en una comprensión de la historia. En síntesis, la autora revisa la relación de servidumbre que se le ha adjudicado al audiovisual respecto al conocimiento histórico y propone caminos para estudiar ambos con una perspectiva que restituya el diálogo que han sostenido.

DOI: $10.17533 /$ udea.trahs.n17a12 